\title{
The Significance of Political Participation in Political Development: A Case Study of Pakistan
}

\author{
Muhammad Ibrahim (Ph.D Scholar) \\ Lecturer Govt. Postgraduate College Bahawal Nagar \\ Email: prof.ibrahim69@yahoo.com
}

Professor Dr. Razia Mussarat

Chairperson, Department of Political Science, Islamia University Bahawalpur

Doi:10.5296/ jpag.v4i4.7189 URL: http://dx.doi.org/10.5296/ jpag.v4i4.7189

\begin{abstract}
The shared and common interweaved concept of public participation for democratization needed accentuate relationship between public and decision makers in democratic institutions. The complex and interwoven issues required more informed citizen. Then it got weighed with debate and discussion for potential decisions. The purpose of the study is to enhance the rate of mobilization high and equality of participation for political development. It also differentiated between modernization and political development. Fast escalations in mobilization and participation, the primary political aspects of modernization, undermine political institutions. The literature that provide is deliberative method for developing principles for public participation. It is art of making people civilized and becoming associated together. It improves the ration and quality of participation in democratization. It is a potential problem to discuss about voting and non-voting. The voting behavior depends upon the techniques of election campaign of political parties. The relation of democracy is linked with political culture has been emphasized. Many authors ponders that democracy rests on a civic culture. The western social scientists as Huntington and Fukuyama connected the religious culture to democratic progression. It is productive for perfection of organization which fortifies democratic institutions for democratization. Public participation decisions are popular decisions. The paper will focus for political development emphasizes on social mobilization and political participation that cause for growth of institutions. That leads to political development of political system of Pakistan.
\end{abstract}

Keywords: Political participation, development, significance, institutional growth. 
Political participation is by no means a new unearthing. The affirmation of political participation is as a pedigree as ancient as politics considered. It is sharing of ideas particular kind of activities about politics. The application of political participation is depend upon politically mature community which strengthens political system. The traditional political thoughts have played no proper role for civil participation. Some particular concepts as despotism tranny, and nature of governing system of state influenced participation of public in politics. The ideas about sovereignty of state and democratic process, citizen ship and basic rights implementation by state institutions support political participation. The violence, tranny, anomie, nepotism and private desires disregard the participation in political activities. It is not mean to lessen participation in political activities.

The process of conducting elections after specific periods is not democracy. Democratic government made efforts to accomplish the norms of good governance to enhance public participation in political system. It makes possible consensus oriented for the participation of peoples in decision making process. The democratic traditions flourish in every field of life of the state. The society has to fulfill requirements for establishment of a democratic government. It proves the tool of satisfaction of public in participation of institutional development process. Fair, free and regular elections are base for the growth of democracy. Good governance promotes the democratic governance which strengthens the institutions. Participatory democratic government is popular notion of political development.(Almond, 1963 p.32)

The democratic performances are remained poor in Pakistan. It can be clarified by several techniques. The constitutional and electoral necessities among institutional factors destabilized responsible and receptive government. The leadership of Pakistan battered by deceitful political personalities and encouraged for self-interest motivation with materialistic benefits and bestowed interests.

Meaningful participation of public in their political affairs is minimal due to education of people about democracy. The effective responsiveness of people is requisite for democratic and governing system. Other-wise, corrupt and hardnosed political leadership is given to political system.

The role of citizen in modern electoral and democratic, or non-democratic or hybrid is studying. After study of 167 political system, it is observed by Gelman world is composite index for public participation.(Gel'man, 2008)There are different factors induced from this study that encompassing five dimensions. These dimensions are electoral process, civil liberties, the operational system of government and political culture. These factors are connected to political participation under political culture. These factors developed political culture which helps in developing categories in lieu of political development. These countries are categorized into four types first are having full democracies, second having flaw democracies, third are hybrid regimes and fourth are authoritarian regimes. The cross-national comparisons of public attitude have absolutely challenging simply having different notions such as democracy different implications in different contexts at countrywide. There searchers have thus disregarded other essential dimensions that are precarious for evaluating different regimes in regard of political development.(Snyder, 2006)

It is expected that greater political participation in United States of America of the region. For the healthy promotion democracy atmosphere, it has to depend upon masses for participation. It is representative input of public opinion about policy matters for development of political participation. The collective efforts depend on decision-making authorities. These efforts are labeled at primary level politically for voluntary assistances in lieu of time and resources by general citizen. The waves of democracy which enhance public participation in Latin American state go beyond. In its procedurals minimums although involvement of citizens is must. This erudite learning about political partaking has been strengthened current consideration to these conceptions. 


\section{$\triangle$ Macrothink}

Journal of Public Administration and Governance

ISSN 2161-7104

Under developed countries are much focused by social scientists to collect information about of respective countries. These developing countries communities labour have opportunities of good social capital. The gain of capital benefits the masses which make citizen involvement in political activity. Robert Putnam's has discussed about influential focuses on the social capital of America. It has turned our attention toward the character in simplifying in the democratization, exclusively in the form of individuals engrossment in political process that confrontational of social capital political life. Putnam laments the weakening in the United States and its repercussions on democratic process of United States of American. He has initiated some studies discovering the assortment of social capital in the United States and well reputable egalitarianisms to discover connection for political participation.(Putnam R. D., 2000) (Skocpol, 2003)

The present era's researchers have paid momentous consideration for social capital character in encouraging the efficacy of democratic systems. The social life depends upon capital which matches to features and norms of social life network. These norms enable participants to live social life and efficiently to follow shared objectives.(Putnam R. D., 1995) Although these concepts are not related to political participation, Putnam debates to extricatetant amount. There is influence between political participation and democratic institutions and social resources have linked among themselves.(Almond, 1963 p.665) It is thinking about the social capital influences the partiality to politically participation. It has rationalized argument about significant indication for decreasing ratio of political sharing in United States. It is concomitant with the erosion of societal capital. The analogous way Henray E. B. S.Verba, with K.L. Schlozman have demonstrated about actions to acquire political participation. The civics kills from their organizational respondents requiring time who are more likely participate.(Verba, June 1995)

The multitudes in current era political participation have to emphasis either on election casting rate or on social movements and popular organizations.(Sidney Verba, 1993)The social scientists classically conduct careful case studies of activating by neighborhood associations, or other popular organizations and successful efforts at human rights organizations. The destitute and the beleaguered can produce effective methods of political participation yet in face of conflict from dictatorial leaders and leading economic elites. The effective mobilizing is tangled with different organizations of communities as groups for human rights and environmental protection for political participation.

There is literature for political participation has to focus on different factors. These factors have social shape to activate political participation. The factors are resources, capital and values for political institutions, opportunities, restraints and other contextual factors. It explores first three factors successively and observes collaboration of these factors in a multivariate exploration participation in politics. There is survey which focus attitudes of people about politics provides direct substantiation for official opportunity, limitations and other appropriate aspects which develop configurations of political involvement. The political participation's study has employed substantial stress on behalf of influential limitations and opportunities in affecting methods of participation chased and the volume of that participation. Institutional role easily enhanced the political participation. To strengthen the issue of public participation in democratic decision making process at institutional level, have to welcome public in the respective field of their interest.

Some factors are, income of individuals, proper education have role which observe in political participation. It is also seen in lieu of city and rustic settlement for inspiring political activity. Scholarly work has reached diverse conclusions. Theorist of modernization has debated about expansion of cities that make political participation easier. Therefore it is higher rates of participation in urban areas. It has other aspect as lack of connection among citizens in urban areas. This deficiency discourages them in appealing combined activities as participating in politics. (Asher, 1984)

The efforts are to discover comprehensively and analytically the assortment of differences about concepts of political participation former historical and linguistic confirmation. The 
stress is given about the concept of political participation. It indicates partaking justice and positioning their actions towards community or conjoint good to members of masses of society. It is closely affiliated with political activities. It is the set of activities and relationships that is to concern for settlement of disputes through public communication which can be achieved with maintaining community fostering cooperation among themselves. The political participation is observed as individuals and groups, within interests of public and reassuring political action. It based upon distinct identification with common concept of correct or incorrect. Other concept of political participation is interconnected with influence and power in comparison of justice and community. Stress is made on idea to protect rights of individual that provide benefits in a competitive framework. Eventually, it is the observed action which addressed the problem of influence in dissemination of politically supremacy. The political activities in turn are assumed as a struggle over infrequent power and possessions. Lasswell's summarizing slogan, "The political process is the shaping, distribution, and exercise of power."(Kaplan, 1950 p.75) The perceptions of involvement as collaboration and participation as influential achievement employ multifaceted and different languages. These are integrating descriptive and explanatory statements analytical claims, statement of standards and recommendations for individuals and their political association.

\section{Agents of Political Participation}

Political participation is linked to the electoral procedures which comprise other techniques more than voting. Political participation is a process that leads to freedom of speak. It gives opportunity to assemble and acquaintance. Further it is the ability to take part in the bearing of public affairs. There is availability of chance to chronicle as a candidate for some elected body and having opportunity to campaign for election process. In this process may be elected and holding public offices at all levels of government. According to international norms of political participation provide equal right to participate in all spheres of the political activities without gender discrimination ofmales and females. Practically it has not fully chances for women to use this right in the world. The women has equal ratio in population it is requisite for political development to create opportunity for their participation. There is need of a special care to ensure their rights are admitted in this regard. There are many developing countries in which women's right are protected in law. No ceremonial legal obstacles for women in participation of political activities in electoral processes. The challenging impediments are existed for active participation of women in politics practically. This political participation is extended beyond the range of parties. Public have to be involved in certain aspects of electoral procedure at local to national level. The public has joining civil society organizations to make strengthen this process. (Report, 2011)

\section{Socio-Economic Issues}

The socio-economic issues also support in political participation. Economic development is link with social life of people which effect the mobilization of masses. Economic development is associated with political participation. The macro socio-economic hypothesis and process is linked with resources, attitude and needs of individuals for political participation. Economic development brings changes in class structure of society. The national development affects the shape of social stratification which altered the substantial structure. The changes in income increased labour promotion for employment which leads to satisfactory with state institutions and make them stable and strengthen. This change benefited to middle class consisted of labour, peasant which is vibrant class of society. The economic development drastically changes in social life of individuals which brings change in political behavior. This increases the trust level on political system. It is requirement of democratic process and political development.(Fung, 2003)

\section{Good Governance}

Good Governance comprehends the apparatuses of state governing system under which public of state articulate their collective interest and benefited through legal rights to meet internal difference. Good Governance system strengthens state institutions which assure people satisfaction to connect institutional participation. The concept of good governance 
connected with active public participation in political system of government. The masses participation in politics makes ensure priorities about political, social and economic issues. These issues handled with extensive consensus in society. To influence decision making process with poorest and most vulnerable populations is not suitable. The resources allocation for development process is linked with public participation in decision-making policies. It is focus to build good governance system to increase popular participation for political development.

\section{Political parties}

Political participation in political affair related to governing system is supported with help of political parties. There are many countries where political parties regulate nomination of candidates for election. This issue issues attain country wide eminence. Therefore political parties get key role for political authorization. The national political parties are determinants of federation. The political parties are most common route to elect representative to run state affairs. The candidates have to depend on political parties for their recommendation and support throughout the election maneuver, monetary funds, and continuous support postelection period. There are many contesting candidates in elections that independently operate their offices without support of parties. There is too difficult to get triumph in election without the patronage of a political association specifically in provincial and federal level. Therefore majority of peoples are looking for party to start politics. The role of political parties varies for participation due to gender domination. The parties have focus specifically issue concern with male and female participation. Political parties are think to nominate women candidates at local level elections. It is easy for women to start political participation at local level then striding to national level politics. The women participation also supports public participation in politics.(Hendriks, 2006)

\section{Non-governmental organizations}

The political parties are performing proper role to enhance the public participation in political process. Non-governmental organizations also have important role in giving awareness to public for development of political participation. Mostly Non-governmental organizations focus on women participation in politics and national development through political participation. These organizations conducted seminars for public awareness in public participation. Non-governmental organizations have specific role in such issues of states. Further on large scale NGO, including rights of females and different groups of community, workers' unions, and other institutions of civil society take parts in several means for improvement of political participation of women in politics.

\section{The effectiveness of Media}

The electronic and print media is playing vital role for increasing interest and behavior connected to election. The media proves responsibility about apprehensions to enhance political participation in political and democratic system. The media transfer powerful edification to voters which give major influence on involvement in electoral process. The results are shown in elections.

The election and media rules construct a framework for specific part in elections. General perception of media coverage about candidates has to be neutral. Many states offer superfluous publicity opportunities for encouragement of political parties to recommend and backing candidates to enhance the political participation. The portrayal of broadcasting system has active role for masses and politicians to boost their political participation. Some kingdoms have high literacy rates that can play significant role in promoting political participation. The media can easily motivate people for sharing in decision making process under democratization.(Pateman, 1970 pp 42-44)

Media played responsible role in the development of democratic society. Pakistani media has leading role. The role of media for the sack of election campaign is important. The results were affected due the electronic and print media's role in election 2002 against the America 
invasion in Afghanistan. The Afghan war changed the political scenario.

The cultural, technological and financial forces are renovating communication about politics, pretention trials and chances for political leaders and media organizations, but meanwhile civil society express apprehensions about the range and nature of political authorization and civic engagement.

\section{The Nature of Democratic Governance}

Democratic government has subsequent three criterion;

-The adult franchise suffrage, that the right of vote for everyone in elections for all adults.

-The selection of representative for government chosen at customary, liberated and spirited election.

-The confirmation of fundamental rights as speech and independence to categorize in groups.(Grerry, 2006 p.20)

According to the democratic norms till 1950, nearly one third nations of world could fulfill the criteria. The efforts for the achievement of democracy have often concerned motivating acts mutually by leaders to public for political participation at large. Democratic governance is process of decisions made collectively through institutions that affects the societies. It is collective decision making method of governance in the society. Democracy needs free, competitive and fair elections, universal suffrage for the selection of government leaders. Democratic form of government entails ensure freedom, fundamental human rights of citizens and competence of deliverance of justice and follows the rule of law. These democratic characteristics flourish the political development process.

The free and fair election for the selection of executive which makes decisions about people is the spirit of democracy. The electoral process is the source of replacement of a government peacefully. The critical situation in democratization is that not chosen in this way by one that is selected in an election. On the whole process of democratization before and after election however is complex and prolonged.(Huntington, 1993 p.9)

When it is discussed about the nature of democratic Governance, then it may be discussed about the democratic politics which based on political participation. Democratic politics is that form of politics in which each citizen in the polity has an equal opportunity to participate. A democracy then is a polity in which democratic politics is the only politics.(Michael, 1979 p.22)

The technology has been considered an idea to political affairs and political speculation. It is fairly in general terms regarding the relation between technology and modernization. A central allege of theories of modernization that technological development that is effecting the political participation in political system. The economic, social and cultural changes also go collectively in rational ways. The revolution of Industrial development altered Western and European countries. The linkage of modernization and development is having differential impact on political behavior of public and state. The intensification of awareness provides foundation with the help of industries and the economy globalization process formed major repositioning in the political beliefs and economy policies. These changes developed their political system which is linked with effective public participation. It is the reallocation of industries with knowledge and structural analysis of the economic situation, the trade policies of world, bring elemental changes in democratic institutions of modern world and civilized society.(Smith, 2009. pp20-30)

The guidance of a group, party, or political entity, typically by an individual that is leader, although style of leadership vary in scope and manner, it is expected that leaders will avoid merely representing the tallied demands of followers, on one hand or engaging in violence or duplicity against them. Leadership is counted on not only to advance interests but also to 
overcome the warring of clashing interests and even to undertake the education and elevation of those interests to broader and deeper views. The leader must combine something of the diverse qualities of the partisan political infighter.(Seymour, 1995 p.725)

The relationship between democracy and leadership is complex and controversial because of political participation. For strengthening of democratization process political leaders are responsible to enhance public political participation. Historically democracies have taken pride in being schools for statesmen but have also suspected and even ostracized them. Theoretically, democracy has been understood both to require particularly virtuous and astute leadership and to require to rejection of all leadership as such. In some sense leadership constitutes democracy after acquiring maximum public political participation. A democracy attitude toward leadership, then, reveals whether it seeks a form of radical or direct democracy. Democracy's attitude toward leaders related to its attitude greatness or superiority. Democratic equality is strong on gaining wide ranging and diverse input but weak on taking decisions or on ranking alternatives. Leaders decide while others satisfied with deliberating; they must concern themselves with private life; and they must break to some degree with prevailing democratic.(Fukuyama, 1993 pp)

\section{Conclusion}

It is studied that political assorted and ethnically divided state has low political participation in governing issues. Minimum participation has impact on governmental affairs. To enhance political participation political parties, media and civil society play a role for development of political development with accordance of modern and civilized world.

\section{Recommendations}

There are some suggestions that can be taken as given follow,

\section{Political party's role}

- The political parties embrace interiorly democratic organizations.

- The political parties should have to focus on proportional systems, space for lower cast, labour, peasant and women as segment of political society. These groups included in contender applicants lists. The parties have to certify they will be adopted, including through such mechanisms as zippered lists, and deliberate voluntary quotas or objects for these segmented contestants.

- Provide support and resources to ensure the maximum political participation in election for their candidates.

- The leaders of political parties have not expectation to win election process freely devoid of fame for dependably fulfilling assurances to the electorates, and the prerequisite to continue this repute should be the vital preventive against vending public parliamentary votes for dishonest private benefits.

\section{The role of government actors}

- The government actors have to ensure laws concern about internal democracy and related issues of elections inside parties.

- The government actors have to consider about legislation in supervision of election commission correlated to political parties in lieu to opt democratization for internal decision making process.

- The government has to consider take steps for political parties to contain a significant percentage for lower cast, labour, peasant and women high on their candidate lists;

- The government has to focus to offer motivations for pressure groups of politics to promote visionary leadership, containing belongings, training and enlarged access to 
transmission time.

\section{The role of International actors}

- The global actors provide assistance and guidance for legislation, election processwith capabilities which enhance participation in electoral process.

- International actors provide assistance for sack of training of political participant candidates.

- International actors provide opportunities for the training to political parties, journalists related to electoral process and law enforcement forces

- The international actors provide support in the training to lower cast, labour, peasant and women who have been elected to run offices. These trainings are to facilitate them for proper performance for new title role.

\section{The role of civil society}

- The media facilitate political leaders at primary level to flourish political awareness to enhance political participation.

- The media has launch a move in masses about political participation

- The media has to highlight the significance of political participation in political system to get share in decision making of governmental affairs.

- The media has responsibility to create awareness in planner of state which has to bound to focus public participation at different levels.

\section{The Role of electronic and print Media}

- The media facilitate political leaders at primary level to flourish political awareness to enhance political participation.

- The media has launch a move in masses about political participation

- The media has to highlight the significance of political participation in political system to get share in decision making of governmental affairs.

- The media has responsibility to create awareness in planner of state which has to bound to focus public participation at different levels.

\section{Bibliography}

Almond, G. V. (1963 p.32). The Civic Culture: Political Attitudes and Democracy in Five Nations. Princeton NJ: Princeton University Press.

Almond, G. V. (1963 p.665). The Civic Culture: Political Attitudes and Democracy in Five Nations. Princeton NJ:: Princeton University Press.

Asher, H. B. (1984). Political Participation. Frankfurt: Campus Verlag. pp. 42-43.

Fukuyama, F. ( 1993 pp). The Primacy of Culture. In T. G. Diamond and M.F Plattner (eds), D, The Global Resurgence of Democracy (pp. pp.320-27). Baltimore MD: Johns Hopkins University Press.

Fung, A. (2003). Survey article: Recipes for public spheres: eight institutional design choices and their consequences. . The Journal of Political Philosophy, 11, 338-367.

Gel'man, V. (2008). Out of the Frying Pan into the Fire, Post -Soviet Regime Changes in Comparative Perspective. International Political Science Review 29 (2) , p.157. 


\section{Macrothink}

Journal of Public Administration and Governance

ISSN 2161-7104

2014, Vol. 4, No. 4

Grerry, S. (2006 p.20). Why Politics Matters: Making Democracy Work. New York: Palgrave MacMillan.

Hendriks, C. M. (2006). Integrated Deliberation: Reconciling Civil Society's dual role in Deliberative Democracy. Political Studies, 54, , 486-508.

Huntington, S. P. (1993 p.9). The Third Wave, in L. Diamond and M.F Plattner (eds), The Global Resurgence of Democracy. Baltimore MD: Johns Hopkins University Press.

Kaplan, H. D. (1950 p.75). Power and Society. Ne Heaven: Yale University.

Michael, M. (1979 p.22). Viable Democracy. Landon and Basingstoke: The MacMillan.

Pateman, C. ( 1970 pp 42-44 ). Participation and Democratic Theory. Cambridge: Cambridge University Press.

Putnam, R. D. (1995). Civic Traditions in Modern Italy. Tuning Out: The Strange Disappearance of Social America. PS: . Political Science and Politics 28 (4)(December.

Putnam, R. D. (2000). Blowing Alone: The Collapse and American Community. New York: Simon and Schuster.

Report. (2011). POLITICAL PARTIES, PUBLIC POLICY AND PARTICIPATORY $D E M O C R A C Y$. Washington: National Democratic Institute (NDI).

Seymour, M. L. (1995 p.725). The Encyclopedia of Democracy. Volume No 111. London:: Roultedge.

Sidney Verba, a. K. (1993). Race, Ethnicity and Political Resources Participation in the United States. British Journal Political Science 23, 457-97.

Skocpol, T. \&. (2003). Civic Engagement in American Democracy, . Washington: Brooking.

Smith, G. (2009). Democratic Innovations: Designing Institutions for Citizen Participation. Cambridge: Cambridge University Press.

Smith, G. (2009. pp20-30). Democratic Innovations: Designing Institutions for Citizen Participation. Cambridge : Cambridge University Press.

Snyder, R. (2006). Beyond Electoral Authoritarian: The Spectrum of Non Democratic Regime,. In A. Andreas Schedler (ed), Electoral Authoritarianism : The Dynamics of Unfree Competition (p. p.220). Boulder Co: Lynne Rienner.

Verba, a. K. (June 1995). Beyond SES: A Resource Model of Political Participatio. American Politic Science Review 89 (2) 271-94. 